\title{
ПРОБЛЕМЫ ЦИФРОВОЙ ТРАНСФОРМАЦИИ ЭКОНОМИКИ ОРЕНБУРГСКОЙ ОБЛАСТИ
}

\author{
(c) 2021 Бекбергенева Дина Евгеньева \\ кандидат экономических наук, доцент \\ Оренбургский филиал РАНХиГС, Россия, Оренбург \\ E-mail:dinabekber@mail.ru \\ (c) 2021 Масюто Илья Александрович \\ кандидат экономических наук \\ Оренбургский филиал РАНХиГС, Россия, Оренбург
}

В статье рассматривается значимость цифровой экономики в Оренбургской области, какие результаты достигаются в области и с какими проблемами приходится сталкиваться. Цифровая экономика - это сложная экономическая структура, основанная на цифровых технологиях, на знаниях, сети Интернет, в рамках которых создаются новейшие цифровые навыки и осуществляется взаимодействие между потребителями и государством. Основное направление цифровой экономики - это ее становление, рост производительности труда, мобилизация возможности ИКТ, снижение бедности, создание новых рабочих мест, а также снижение общественного неравенства в мировой интеграции в целом.

Ключевые слова: Цифровая экономика, информационно-коммуникационные технологии, Электронное Правительство, Информационное общество Оренбургской области.

\section{Введение}

Сегодня, цифровая экономика как направление является актуальной темой для обсуждения. Она представляет собой грядущую ступень развития глобальной экономической системы, открывает новые возможности.

Новые возможности открываются перед человеком благодаря развитию цифровой экономики, и это конечно же в основном положительные изменения. Цифровые технологии технологии хранения, сбора, обработки, поиска, передачи и представления данных в электронном виде. Благодаря цифровым технологиям, потребитель может экономить деньги в связи с тем, что цены в интернете часто ниже тех, которые представлены в обычных магазинах, а также значительно быстрее получать заказанные услуги. Использование информативных технологий приводит к улучшению качества услуг, условий управленческого труда, разрешая значительно увеличить его результативность, тем самым повышая эффективность деятельности органов исполнительной власти Оренбургской области и органов местного самоуправления муниципальных образований Оренбургской области.

Само представление «цифровизация» говорит о новой стадии улучшения управления производством товаров и услуг и самого производства.

\section{Значимость цифровой экономики}

Формирование цифровой экономики предполагает преобразования во всех сферах жизни и деятельности людей.

С появлением новых технологий начали происходить улучшения в сфере образования в учреждениях, здравоохранения в городе, начался меняться трудовой рынок.

Цифровые технологии и их распространение в течение длительного периода определяют траекторию развития общества и экономики и уже привели к кардинальным изменениям в жизни граждан.

Разнообразные новые навыки и знания нужны для освоения цифровой экономики, абсолютно новых мер как социальной защиты, так и качественно нового соотношения между отдыхом и работой. Понадобятся большие инвестиции для развития образования, которые будут направлены не только на сам процесс обучения, но и на обучение методам организации данного процесса, а также обеспечения всеобщего доступа на протяжении всей жизни к образовательным услугам.

В настоящее время хорошие итоги достигнуты в процессе внедрения ИКТ в деятельность органов исполнительной власти и местного самоуправления Оренбургской области, обеспечивая 
значительный вклад в решение проблем всего общества, таких как экологические проблемы, повышение конкурентоспособности компаний, создание новых рабочих мест.

Обратимся к опросу Оренбургских жителей по вопросам использования населением в возрасте от 16 до 70 лет ИТ и информационнотелекоммуникационных сетей (ИКТ). Каждый четвертый житель области использовал сеть Интернет для заказов товаров и услуг. Больше половины использовали для получения услуг, таких как здравоохранение - 39\%, налоги и сборы $-19 \%$, услуги МВД - $13 \%$, образование $-11 \%$, паспортные услуги - 8\%, ЖКХ - 6\%, социальное обеспечение - $4 \%$.

Судя по данной статистике, можно сделать вывод, что сравнивая с предыдущими годами, жители Оренбургской области стали чаще использовать новые ИТ.

На данный момент тенденция уделять не малое внимание своему здоровью у граждан растет. Онлайн-технологии позволяют делать лучше и удобнее современную медицину за счет постоянного наблюдения состояния здоровья граждан. Это позволит в будущем вывести медицинскую сферу на новый уровень развития.

Особое внимание уделяют государственным программам, нормам и правилам, которые должны обеспечивать многообразие технологических решений.

В целях развития информационного общества и создания условий для развития цифровой экономики с 2014 года в Оренбургской области действовала государственная программа «Информационное общество Оренбургской области на 2014-2020 годы», утвержденная постановлением Правительства Оренбургской области от 23 сентября 2013 года N 790-пп.

Итоги достигнуты в настоящем времени в сфере региональной информатизации. Создан информационно-телекоммуникационный и технологический комплекс, который является фундаментом формируемого «Электронного правительства» Оренбургской области. Основными компонентами, которые функционируют в составе «Электронного правительства» области, являются инфраструктурные системы электронной почты, электронного документооборота органов государственной власти, поддержки казначейского исполнения областного бюджета, государственный центр обработки данных и др. Областные органы законодательной и испол- нительной власти официально представлены в Интернет порталом Органов государственной власти (www.orenburg-gov.ru) и порталом Муниципальных образований Оренбургской области (mo.orb.ru). Информатизация Оренбургской области развивается также на муниципальном уровне. Строительство продолжается дальше «Электронного правительства» Оренбургской области с расширяющимся охватом наиболее популярных процессов государственного и муниципального управления.

Одними из главных направлений информационной политики являются расширение информационного потока о социальноэкономическом развитии Оренбургской области, продвижение и поддержка проектов евразийского сотрудничества, создание условий для осуществления новых информационных проектов.

На Едином портале государственных и муниципальных услуг представлены сведения о 308 переведенных в электронный вид государственных и муниципальных услуг, из которых 286 - государственные услуги, 22 - типовые муниципальные услуги (в 2010 году - 52 услуги: 2 - муниципальные, 50 - государственные). Количество государственных и муниципальных услуг, оказанных в 2018 году в электронном виде с использованием Единого портала государственных и муниципальных услуг, составило более 1200000 единиц (в 2010 году - 17 информационных услуг).

В рамках реализации мероприятий, направленных на развитие информационного общества и построение электронного правительства в Оренбургской области, за период с 2010 до сентября 2020 года были достигнуты следующие значения показателей (индикаторов):

- доля домашних хозяйств, имеющих широкополосный доступ к сети Интернет, в общем количестве домохозяйств области в 2020 году составила 86,1 процента;

- количество линий ШПД на 100 человек населения области достигло 31 штуки (17 штук в 2010 году);

- доля сельских поселений Оренбургской области, имеющих доступ к инфраструктуре электронного правительства Оренбургской области, в общем количестве сельских поселений Оренбургской области - 99,0 процента (в 2010 году - 0,1 процента);

- доля сотрудников органов местного самоуправления и исполнительной власти Орен- 
бургской области, прошедших обучение в сфере использования информационных технологий, в общей среднегодовой численности сотрудников органов местного самоуправления и исполнительной власти Оренбургской области составила 93,0 процента.

Отрасль информационных технологий Оренбургской области на 1 января 2020 года была представлена 823 индивидуальными предпринимателями и юридическими лицами, из которых 140 осуществляют деятельность в сфере разработки ПО.

При имеющихся достижениях в использовании ИКТ в Оренбургской области присутствует ряд проблем:

- в связи с ухудшением эпидемиологической ситуации - распространением новой коронавирусной инфекции Covid-19 часть юридических лиц и индивидуальных предпринимателей были закрыты;

- недостаточная эффективность государственного управления процессами внедрения ИКТ в области;

- недостаточный уровень информатизации социальной сферы Оренбургской области.

Региональный проект «Информационная инфраструктура» является частью подпрограммы «Цифровой регион» государственной про- граммы «Цифровая экономика Оренбургской области».

В этом проекте обращают внимание на эффективность и результативность предлагаемых мер.

В ноябре 2020 года доступны 173 государственные услуги жителям области Оренбургской области.

На основание представленной информации видно, что в 2020 году доли органов власти, которые имеют доступ в сеть Интернет со скоростью не менее 2 Мбит/сек, в общем числе органов власти федерального, регионального и местного уровней достигла значения 70,0\% (в 2014 году данное значение было всего 51,30\%), тем самым превысив ожидаемое значение на $18,7 \%$.

Спрос на онлайн-технологии, в общем, имеет динамику положительную. Число пользователей, использующих сеть Интернет, значительно растет, уровень информационнокоммуникационных технологий соответствует современным тенденциям.

В области формирования регионального информационного пространства Правительством Оренбургской области оказывается многосторонняя помощь формированию районного телерадиовещания, областных информативных площадок с целью обсуждения социально важных вопросов.

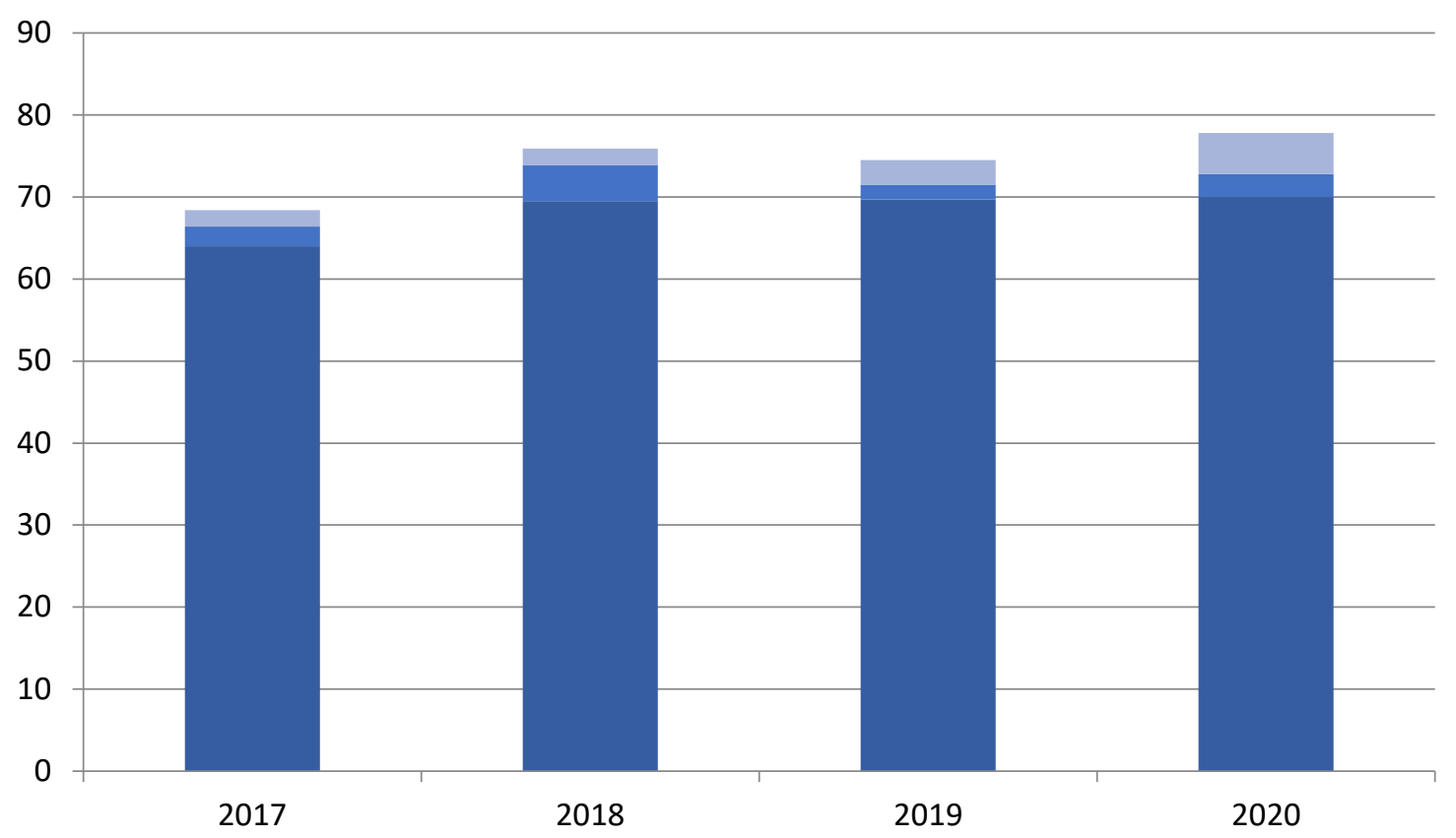

Рисунок 1. Доли органов власти, которые имеют доступ в сеть Интернет со скоростью не менее 2 Мбит/сек, в общем числе органов власти федерального, регионального и местного уровней 


\section{Заключение}

Таким образом, исходя из многолетнего опыта создания новых инноваций, вопрос развития и формирования цифровой экономики считается актуальным. Чем быстрее внедряются новые технологии, проекты, тем сложнее появляются задачи в области управления становления цифровой экономики. Онлайн-технологии становится причиной исчезновения множества профессий, но одновременно и появления новых.
Обществу предстоит искать пути решения таких последствий цифровой экономики как: низкий уровень доверия к онлайн-технологиям, замена традиционных рынков. Но это позволит хранить доступную информацию в больших объемах, ее обработку.

В настоящее время достигнуты значительные результаты в процессе внедрения ИКТ в деятельность органов исполнительной власти и местного самоуправления Оренбургской области.

\section{Библиографический список}

1. Постановление Правительства Оренбургской области от 29 декабря 2018 года N 917-пп «Об утверждении государственной программы «Цифровая экономика Оренбургской области» [Электронный ресурс] Режим доступа: http://docs.cntd.ru/document/550336336

2. Постановление Правительства Оренбургской области от от 23 сентября 2013 года N 790-пп «Об утверждении государственной программы «Информационное общество Оренбургской области» [Электронный ресурс] Режим доступа: http://docs.cntd.ru/document/460185772

3. Алексеев И.В. Цифровая экономика: особенности и тенденции развития электронного взаимодействия.

4. Бекбергенева Д. Е. Характеристика и ключевые решения процесса построения цифровой экосистемы // Экономика и предпринимательство.-2020.-8(121). С 1080-1083.

5. Бекбергенева Д.Е. Исследование показателей инновационного развития России в условиях цифровой экономики // Экономические науки. - 2020. - № 184.- С. 41-46. 